\title{
ACTUALIZATION OF LEADERSHIP AS A KEY CATEGORY OF NEOECONOMICAL COMMUNITY: SOCIO-CULTURAL AND EDUCATIONAL ASPECTS
}

\author{
ANNA GRIBOVYCH, OKSANA KONDUR, YAROSLAV MELNYK
}

\begin{abstract}
The problem of leadership as a key category in the formation of a new generation of socially active and business people is examined in the article. To our time, the leadership and initiativeness are described in a large extent within the framework of the training of the university specialist category. It is proposed to bring it to a wide educational and professional position and to focus its attention on the university system. The reorganization of the higher educational system is also proposed, taking into consideration the need for actualization of leadership by itself. The results are interpreted in the framework of humanitarian, political, economic, social and demographic problems of Europe at the beginning of the XXI century.
\end{abstract}

Keywords: leadership, education system, sociology, economic policy.

\section{INTRODUCTION}

The development of civilization in the last decades has been affected by specific socio-cultural, political, migration, demographic, economic, environmental and other processes where the humanity has never encountered before. The obviousness of these processes is implicit, because they are clearly manifested in the point of crisis phenomena that are now experiencing the human community and the surrounding reality [1]. The need to reformat knowledge in many areas of our lives and replenishment of the new information is beyond doubt. These problems are rapidly discussing at all levels and are an integral part of mass-media, political, economic, and sociological discourses. A large number of symposiums, conferences, seminars, sayments, etc. do not give perceptible results. The key, strategic goal of global and sectoral programs is to create a favorable, stable, strategically based climate for the survival of a human, civilization and the environment. The attempts to solve these problems are taking place against the backdrop of globalization processes, the essence, nature and the consequences which are still not investigated [10].

The course of political and economic, social and other processes take place under the new conditions, which had not been so relevant so far, so the researchers avoided them with their attention. In the most details, it is a matter of unprecedented migration and assimilation processes, information wars, religious and ideological confrontations, ecological (both natural and antropogenic) catastrophes, etc. It is also indisputable that these processes take place under the laws of dialectics, the laws of nature 
and the laws of the development of human society. There are obvious facts of evolutionary entropy before us. A human as is known is not unable to coordinate and manage these processes in handy way. Nevertheless, a separate segment of these processes (evolutionary dynamics) can be regulated by human intelligence, and be controlled by separate social, scientific and state institutions. The regulatory function falls on the scientific, educational, mass media, legislative, social, economic, military and other structures, which by definition have to study, influence, predict the course of certain events. It means that scientific knowledge, strategic information, historical experience, competence and knowledge of laws, as well as the corresponding structures have the responsibility for our present and the near future. It also should be noted that such "responsibility" is not a precedent, since human activity has never been so influential on evolutionary processes and on the environment. And if the evolution of past epochs and cultures took place spontaneously, unknown laws and the factor of conscious control over the course of historical events were minimal, then in our days the function of regulation or programming of the development of civilization, cultures, social spheres, economic dynamics, environmental influences and others is significant. In other words, the mission of human intelligence is significant and an "uncontrolled spontaneity" of the development of civilization under certain conditions can be minimized.

Thus, we should accent on knowledge, competence, fundamental and applied sciences, educational programs and various social and political institutions are a significant part of responsibility for our present. Accordingly, and solving of these problems should be made in these flats [21, p. 8, 11, 102].

The purpose of the article is to emphasize the research on the phenomenon of personality, its cultural and ethical characteristics, levels of competence and spiritual development, on the ability to develop their social and role potentials and implement them in a specific socio-cultural and spatial-temporal format/Some aspects of this issue were addressed in $[3 ; 11 ; 13]$.

\section{RESULTS AND DisCUSSION}

Taking into consideration the specifics of the European geopolitical and socio-cultural space, we will focus our attention on the fact that the picture of the last two decades is fundamentally different from all previous epochs. It is about the elimination of borders within Europe, the intensification of migration processes, national, economic, social regrouping, actualization of any phenomenon in the Euro-format (social groups, small or big business, local or non-local military operations, the formation or disintegration of state micro- or macro-systems, the tendency toward the cosmopolitanization of the European mental culture, etc.), on this way or another one, receives a European and general planetary reading (for example, the collapse of the Soviet Union as megasystems, the disintegration of Yugoslavia is more localized variant of the state and political transformation, the formation of the European Union, the entrance, and now Britain's exit from the European community, the aggressive policy of Russia, etc.) - all these events have influenced and are influencing on the world political, economic, ideological and philosophical climate. In other words, any element of the state or sociocultural system must be interpreted both in the framework of the local subsystem (subordinate system) and as an integral system element (megasystem) [15; 18]. It means that traditions, culture, legislative systems, ethical norms and others of classical Europe are relevant not only within the limits of the old continent, but also for the whole world, for all regions of the planet, where the human population is represented. In addition, any program, idea, action that is launching and has a chance to be implemented, should also be interpreted as an element of the macrosystem. It means that every element in the whole system of coordinates, both of them the European and global, that is (like "I" or "he" and anything "read" in this flat and in this context, whether my staying is comfortable for me and for others?) [1].

Leading researchers in various fields of science say about such or similar interpretations $[2 ; 4 ; 7 ; 17$; $21 ; 22]$. It means that a modern person (it concerns a young and promising person who is preparing for active social and economic activity, who is standing at the beginning of a life road and wants some selfrealization and career growth, etc.) should be set on the fact that it it will have to be self-realizing in a 
multicultural world, where world-view multi-polarity will be the norm. There will also take place a permanent tendency to surrogate languages, cultures, cultural and aesthetic, religious, values, and other phenomena. This, in its turn, will require from the modern businessperson new social, psychological, intellectual (here, and communicative, analytical and synthesizing, cultural and adaptive, etc.) qualities, as well as skills of work, productive activity in a new cultural and multi-vector environment. New living conditions will require qualitatively new communication skills, it means, especially new choices for collegiality and team building, new forms of cooperation, and (as we pay particular attention to) new conditions and leadership principles.

Speaking about leadership, about its classical interpretation, we note that it also contains such conceptual categories and attributes as initiative, responsibility, ability to orientate in the information space, possession of various types and genres of communication, possession of a wide range of imperatives - forms of expression of will, order, offer, instructions and others, ability to use the given audience and management potential, ability to work in a team and organize it and focus energy on a specific problem segment [leadership] [12; 19; 20]. Such and other qualities require and demand the objective reality of an adapted and motivated young person who will take a socially active position in society.

However, it shows us, that today, working with younger generations - school, gymnasium, university or postgraduate age - it is necessary to lay bricks for a new way of thinking, new models of social behavior. It should also be noted that such updating of leadership features and skills should spread not only to the category of young people in whom these abilities are already manifested and the system of education and socialization is engaged exclusively in the "cultivation", organization and information provision of these nature by initiative young people It means that training, preparation, and stimulation of such activities should reach the widest range of young people, since, as it was noted above, their unequivocal majority in the perspective - life, activity, different situations will require leadership skills and qualifications - this is an absolute condition of a new integrated society.

Thus, the epicenter of our attention was the phenomena of genealogy, the formation, construction of a new type - a human being of a social, human-communicant, human-leader, human-initiator, man-performer and human-manager, a person who is able to adapt in the information environment, in complex multi-vector social configuration, while possessing the skills of an analyst, psychologist and creative manager. A young businessperson also must have a high culture of communication and tolerance, be psychologically able to take responsibility for the decision, develop a program of action, and be able to run a mechanism for the implementation of these decisions. In addition, an important factor in strategic thinking and the ability to calculate possible risks, etc [6]. Concerning the last position, attention should be paid to its relevance. The development of any strategies, prospective planning, implementation of any programs require hypothetical estimates of possible miscalculations, failures, errors. As historical experience has shown, a significant number of global or micro-projects (political, economic, social, etc.) collapsed because a systemic analysis and a prolongation system on possible failures or risks were not done. The current level of designing of any system requires both a holistic and phased assessment and validation of the probability of possible deviations.

Relying on research in the field of sociology, ethno-cultural studies, demography, ethnopsychology, discourse and methodology for the formation of social groups, and sketching out these models, one should always expect challenges in the form:

- unreliability of individual segments of the system, irresponsibility or asocial behavior of individual members of teams (groups, unions);

- propensity to simulate activity (imitation of high-quality, productive work) on the background of its significant inferiority;

- low level of professionalism of individual partners or team members, inability (unwillingness) to work in a team, unwillingness to make collective decisions;

- excessive ambition of individual team members;

- inability to work in the legal field;

- propensity to adopt bureaucratic behavior models;

- worthiness and propensity to use corruption schemes (illegal rewards); 
- uncertainty (disproportion) in the aspiration to make a career in the event of failure to operate the relevant categories;

- insufficient level of education, (and sometimes low level of IQ of separate team members);

- divergences in the interpretation of the institutions of democracy, in particular in the perception of gender institutions;

- dissonance in the sphere of interpretation of religious and ideological categories (that modern poly-cultural Europe demonstrates us, which puts an effort to create a zone of comfort for different religious-ethnic groups, there remains a large number of unresolved issues, and they are constantly replicated and complicated);

- incapability to integrate into the European environment certain members of the team for which Europe is not a historical homeland;

- the factor of previous work experience (previous life practice), whose inertia is superimposed on mental and social behavior (let us consider, a young man who took part in fighting in one of the "hot spots", after the release of troops with significant difficulties integrates into a new, peaceful reality);

- incapability of a flexible, tolerant, diplomatic, within the ethical field to discuss and solve problems;

- incapability to navigate the global information environment and to identify dominant segments that require urgent audit interference;

- linguistic and communicative poverty and lack of floodgates (possession of only one language, if necessary, at least 4 different languages);

- the problem of "tiredness", "exhaustion" of a modern business man, his spiritual and moral stability, the ability to continuously vital and strategic renewal (the ability not to fall into depression, which became a real epidemic for the civilized world);

- the ability to read the "book of life", to be in the human environment, not to be overwhelmed by virtual systems (which has become a global problem for the USA and Western Europe);

- spiritual worldview poverty and unwillingness to be enriched; reluctance against the background of basic employment, take an active social position, and support humanitarian, volunteer programs and actions, etc.

This is just a small list of challenges faced by group leaders and young members of these groups today. Actually, their solution is just as relevant as the socio-economic activity itself.

Leadership issue, as it was mentioned above, it is not a format of problems that affects a small group of already identified individuals, but the problem of giving young people all the skills of the preschool, school, and university students, and programming a young person in this kind of activity.

At this stage, we can generalize that the formation of a leader (different levels) is one of the key tasks of the modern humanitarian program [14]. Leadership as a self-sufficient, creative system of world perception and social connections, as well as a category that incorporates such components as: initiative, responsibility, competence, psychological and moral integrity, mobility, adequate inclusion in a complex social and informational context [16]. These characteristic features, which should be inherent to any young person who pursues the goal of being installed in the modern business world. These problems require a comprehensive solution and the correct setting of tasks - first of all, various humanitarian programs and educational establishments, mass media and cultural-educational programs, youth organizations, and others.

Against the background of the outlined, in the future we will have to solve the issues of social and informational self-regulation, which today is relevant in most developed countries. Today's young human almost in his childhood creates his own virtual world, interprets it as an alternative reality. An excessive immersion in this world brings a serious destruction in its socio-worldview of the world. Such a young person is quite progressive from the point of view of information and technical ability to self-fulfillment and it corresponds to the format of time, but as a carrier of individual social programs, the socio-cultural segment, it in most cases loses it (as a socially deterministic subject, as a personality). Young person is often self-isolated, lives in the world of his/her illusions and virtual contactors. Therefore, for him/her, the outbreak of living social contacts is threatening and traumatic. This is one of 
the key social problems of the modern developed world. It is followed by heated disagreements and discussions at various places discussing the prospects of information and technological future of civilization [5]. In this context, the problem of leadership (initiative, implementation of life strategies) sounds very actually and in a special way and requires a new interpretation.

One of the key issues is the provision of humanitarian programs for a modern young human, and in some cases, their significant correction, competent intervention in this area, reloading of the information space (and as a result educational curriculum) and the "returning" of human to society, human community, and the providing of necessary skills of social contacts, communication, initiative, leadership.

By narrowing the topic to the applied tasks, we will single out a few priority factors. One of the key tasks will be to consider the need to reform the system of education and upbringing in such a way that from the preschool age, completing university and postgraduate education, methods have been worked out and applied to identify and form leader personality traits [11]. Particular emphasis should be put on the formation itself. It deals with that fact that in most children of junior and middle school age these features and abilities are deeply latent. Detection, demand and implementation of them in standard life situations is unlikely. Only extraordinary cases or randomness can cause their transition into an obvious format. At this stage of development of a child, leadership features can be found only in certain children, which are the formed feature of nature, socio-psychological need, the result of gained experience, the upbringing or conditions in which the child lives. But, if we rely on the thesis that in the future most of them will have to be integrated into the active and business world, motivated, installed in microcosms, the common feature of which will be business activity, then business qualities: initiative, leadership, responsibility for a separate area of work and integral program, the ability to perceive adequately other people's ideas and defend their position, to search for the correct solution to the problem, compromising attitude the ability to collectively (in a team) solve complex issues, determine the priorities at each stage of the program, perseverance, flexibility and awareness of the need for applying different tactics (sometimes deviant to give some principles for the final result); the need for career growth and others. is a necessity and a need, a condition of a future specialist.

In addition to these features, modern business human (and the nearest future) should operate in such categories as: understanding the need for project development (preservation of "self-action" of the company, the program); to realize the need for a tolerant attitude to the competition - the inadmissibility of any antagonism or aggressive attitude towards the opponents; have a high level of imperative culture - have a wide range of implicit and explicit forms of imperative, as well as a significant tool of euphemistic techniques for smoothing or neutralizing potentially or openly dangerous parts of communicative and business programs; owning a disputant culture - a significant range of dialogic techniques; the ability to think unconventionally and find extraordinary decisions, etc. that are obligatory for a future business person. It is absolute that there should be created a system, a set of conditions that will facilitate the identification and formation of these features. The complex should consist of: a consistent, dynamic, logical and logistically substantiated, hierarchical set of measures that in result will give an identical personality, directly proportional to the era in which it will have to live and self-fulfillment.

In the context of mentioned above, let us note that the special responsibility for the formation of these qualities in a young person falls on the university system (for the establishments, which are providing educational services for the 15-30-year-old age category of citizens). It is especially in this period that the process of determining the main priorities for the individual person, preparation for integration into the socio-economic system, the choice of profession and lifestyle, the definition of the system of values, preferences, and others. At this stage, the mechanism of "formatting" of the person should "work" [8]. Also, depending on the person's choice of future employment, its psychologically and communicative model must "complete" the features that will be needed in the future. So, let's say, if a young person chooses to work in the police or military service by his sphere of activity, so then at the same time he/she chooses a set of skills, leadership abilities and there should be present: the ingenuity, creative thinking, the ability to analyze the situation and react adequately to it and it should be an obligatory condition of the future profession. If a person chooses an economic, business, political, 
scientific or any other socially active sphere of activity (even if it is a craft or performing different kinds of work in the service sector), this choice also requires organizational skills, leadership skills. Moreover, even a family circle, a standard of living requires such skills and characteristics.

From the wide-ranging interpretations we will turn to more substantive deployments of this problem. The role and place of the university system (the educational branch that corresponds to this age category) is very important in the implementation of a new concept. Any establishment of higher education should not be limited only to educational services, but also to train the skills of a leader, manager, organizer, creative manager. In order to provide this kind of information support, a higher education establishment should become a laboratory, a platform where a young person can get knowledge, learn and apply the experience of a leader. It is known that only military and police educational establishments always provide their graduates with experience that almost does not extend to civilian facilities. It means that soon the experience of military and police educational establishments should be applied in civilian cases. Here we are talking about a small correction of educational systems. Its vector redirection to a plane in the epicenter of which will be responsible person, person-leader, initiator, organizer, manager. In order to implement such programs, as noted above, the university system should be first of all reorganized [9]. It is not about fundamental changes in the university management hierarchy. The millennial experience of university education has performed various stages of formation and improvement. It is self-sufficient and perfect.

However, the 21st century introduces new requirements and criteria.

Among all these requirements, the most important are:

- taking into account the factor of globalization processes;

- consolidation and monolithization of information space;

- wide request for high (higher) education (competence and professionalism);

- access to higher education of all sections of the population (the only condition should be the availability of high-quality basic education);

- a gender reorganization of the education system (over the past hundred years, higher education in masculine education has been transformed into feminine, which in its turn is a new trend.

The question of the financial distribution of the modern world remains relevant - according to statistics, $2 \%$ of the planet's population is concentrated on $87 \%$ of the financial mass. Such a disproportion has all the signs of a monopoly and is the legislator of the economic climate on the planet. An important factor is also that the countries of the Far East are China, India and others become financial and economic heavyweights at the beginning of the XXI century. Besides, the most important players in the world economic market are the countries of Asia and Africa. It means that such economic reorganizations imprint a global socio-economic model. The picture of energy carriers remains over actual.

In such a way the civilization entered the 21st century. In this context, the factor of activation of the "Third World countries" in the direction of actualizing their role in the current political and economic picture of the world. As a consequence, the efforts of a significant number of representatives of the Asian and African continents to gain European education and "run" their business programs both in their homeland, and in Europe, America, and East Asia. These and other factors influence on the world system of education. Therefore, the establishments of higher education, their level and quality of work are assessed both within countries and on a global scale, their rating and degree of prestige is determined. Such an interpretation of the status of establishments is also determined by the fact that the future elite of nations is formed in their walls. Their students will fill their study-rooms, offices, administrative establishments, parliamentary halls and will determine the course of history in a short time.

In accordance with the new requirements, educational systems must bring out the number of students to a new level of self-organization and correct the focus of their attention and transfer from a specialist to a person-leader, a responsible person, a person with a high level of internal culture. The leader in this format is not only a guide, chairman, alpha-person performing key organizational (GPSfunctions). Moreover, a person with high moral and ethical qualities; the leader is an analyst, strategist, 
honest player in any game, a person responsible for flexible thinking and world perception. Obviously, these are the only and general requirements for a modern businessperson. A departure from these basic settings will inevitably lead to the emergence of self-taught, people with a low level of spirituality, intelligence, and business culture will occupy the positions on the world stage of leadership. Quite often, as experience shows, they are vested with hypertrophied ambitions, and because of their activity, there may be new totalitarian regimes, tyrants, "evil empires", aggressive systems (a great master class was demonstrated by the XX century because most of the leaders of totalitarian fascist systems were ill-educated, which intuitively defined forms of government, the main motivators of the leaders of these countries were not competence, knowledge, high morals, ethics and self-respect, but fear, intolerance, antagonism, unhealthy ambitions. Therefore, the traditional and a characteristic feature of these systems were a monopoly on power, tyranny, aggression, legal mess, bureaucracy, the destruction of cultures and economies) [2].

Therefore, in the organization of the educational system (we are talking about university level), the development of its new concept, it is necessary to look for a rational grain, the optimal value, in which the factors that are discussed above are to be updated. It should be noted that here are two key aspects:

a) reorganization of the system of higher education;

b) changes in the system of training specialists.

The first aspect should include the following factors:

- attract and intensify the experience of the advanced and most advanced educational establishments, namely: colleges and universities of Britain, Europe, America, Japan, etc.. To study this experience and reprogram the work of higher educational establishments of Ukraine in accordance with their norms and traditions.

- for administrative positions - leaders (chairmen) of different sectors should be established age requirements, as administrative work requires analytical brains, rapid orientation in the information space, adequate response to different types of innovation and change;

- students should conduct systematic (semester) questionnaires (sociological surveys), the results of which will be determined by the rating level of the teaching staff.

- the same poll should be conducted among teachers in the assessment of the university leadership group. These questioners will allow you to identify and respond adequately to potential negative trends in a timely manner.

- distribution of university representation in the academies of sciences, higher councils (ministerial, parliamentary levels, senate, etc.), which carry out general coordination work,

- to implement the program of cultivating leadership as a mandatory feature of a modern business person, establishments should be given greater autonomy.

As the experience of research structures of different levels and degrees of complexity have shown, only local structures have the property of rapid adaptation, are mobile, convenient in management and vested with the highest degree of "self-action". Here again we can turn to the British experience and bring a pattern - most of the educational establishments that are endowed with such autonomy and do not "drown" in the paper sea reporting, but the level of educational services is the highest in the world and the leading political, economic or other leaders at the same time got their education exactly in these establishments.

In order to prepare a young, socially active generation with a wide range of thinking, it is necessary to invite specialists from other establishments for short cyclic lectures. The percentage of such forms of work with the audience should not be less than $40 \%$. The constant "circulation" of the teaching staff (for reading special courses) will bring a stream of "freshness", novelty, deprive the educational process of conservatism, give a high level of alternative solutions and views on the problem. Such applicability of knowledge and communication is a pledge and one of the conditions for qualitative preparation and formation of leadership features in the younger generation.

The next stage in the formation of leadership features is the actualization of those programs that will reveal and promote the enrichment of leadership experience. These include the following segments: 
- in the educational programs, the following disciplines should be introduced (to expand their teaching) such as: logic, logistics, ethics, basics of analysis and synthesis, system theory, management psychology, conflictology, theory of reasoning, theory and practice of games (theory of games), theory of communication, the theory of information systems, etc.

To strengthen the discipline of knowledge (responsibility for social and communicative actions), innovative projects, master studies should be introduced into a single database (state or European information space). This form of information installation will help in the future in the searching of young specialists by employers and vice versa.

The question remains the possibility of going through different types of internships and approbation of projects in real conditions. A young specialist should be immersed in at least for a short period of time in the environment of those factors and factors that are envisaged by the terms of his project, in order to identify his organizational, leadership abilities and opportunities to realize his projects in real life (spatial-temporal) frameworks. Therefore, different forms of practice, field and industrial practices, internships, etc. is a necessary condition for the expression of leadership characteristics.

\section{CONCLUSIONS}

Though, there is no doubt that the modern business world requires a specialist of a certain analyst, a broad world view, a system of thinking, high adaptive qualities and, the most important, one way or another of leadership skills. In other words, leadership should be taught, as well as any other discipline. It is necessary to develop a set of methods, techniques and measures that will help to identify existing organizational skills and to continue the formation of business people. This complex is not limited to school and university education, it goes beyond the educational programs and reaches all state political, economic and socio-cultural systems. To realize the concept of leadership, one must realize that every active member of society must be endowed with this trait, as well as responsibility; the ability to be compromise and tolerant and to live and act in the legal field (respect the legislative canons developed and used by the international community or any micro-socio-cultural system); be adapted to international and individual cultural and ethical standards; must possess a complex of communicative styles, in order to use one of them if there will be a need; must be guided in the system of imperative structures and possess different forms of expression of will (which is an obliged condition for the formation of leadership qualities); knowledge of several multi-system languages that will make it possible to get rid of the complex of linguistic communicative inferiority (to be a leader in the modern world and to speak only one language is impossible); to be responsible for a pronounced word - it should have weight and for it the speaker must be responsible; have high-quality professional training within the narrow specialization, as well as navigate in other adjacent and sufficiently remote areas - to understand the general political, economic, socio-cultural, demographic, and environmental trends, etc.; be psychologically trained to work with other leaders, individuals, groups; constantly engaging in self-education, improving personal skills, self-analysis, etc. It is the system of educational preparation, ethical and legal, socio-cultural, informational, mass media and others systems should be largely redirected to leadership formation (this largely coincides with the formation of the individual)., as an organic and inseparable features of a modern business person. The lack of leadership abilities and skills should be regarded as elementary computer or any other illiteracy, etc. the leadership is a strategy, one of the basic categories of modern businessperson, and, at the same time, a software modulator that should affect the prospects of the formation of the business world. Taking these elements into account today is a necessity in view of the fact that the development and implementation of the programs will require a considerable time resource, and also the axiom is that the correct formulas for solving such problems are not always present, testing and different types of corrections are also needed there will be time expenditures. It means that there is now an active discussion and solving of the leadership problem in the context of the formation of a business and balanced world. 


\section{REFERENCES}

[1] Brooke S.I. Population of the World. Ethnodemographic Guide. Nauka, Moscow, 1986. (in Russian)

[2] Gachev G.D. The Mentality of the Peoples of the World. Algoritm, Eksmo, Moscow, 2008. (in Russian)

[3] Gribovych A. Modern Theories of Leadership in the educational Industry. The actual Problems of Regional Economy Development, 1 (14) (2018), 46-52. (in Ukrainian)

[4] Gumilev L.N. Ethnosphere: The History of People and the History of Nature. Ecopros, Moscow, 1993. (in Russian)

[5] Foucault M. Archeology of Knowledge. Osnovy, Kyiv, 2003. (in Ukrainian)

[6] Furman A.V. Methodology of Paradigmatic Research. Economic Thought, Ternopil, 2013. (in Ukrainian)

[7] Hura T.V., Ponomariov O.S. Social and psychological demands on leader's personality and character of his thinking. Problems of Modern Psychology: Collection of research papers of Kamianets-Podilskyi Ivan Ohienko National University, G.S. Kostiuk Institute of Psychology at the National Academy of Pedagogical Science of Ukraine, 34 (2016), 90-102. (in Ukrainian)

[8] Johnson A. Explanatory Dictionary on Sociology. Publishing Center of Ivan Franko National University of Lviv, Lviv, 2003. (in Ukrainian)

[9] Kondur O. The corporate management of higher educational establishment in the conditions of educational modernization. Educational Space of Ukraine, 11 (2017), 63-70. doi: 10.15330/esu.11.63-70 (in Ukrainian)

[10] Kondur O.S. The main tendencies of transformation of educational systems in the context of ideological foundations of global social development. Społeczeństwo. Edukacja. Język, 7 (2018), 203-215. doi: $10.19251 / \mathrm{sej} / 2018.7(16)$

[11] Kondur O. The component of managerial of professional competence of a specialist in the education system. The Sources of Pedagogical Skills, 21 (2018), 95-99. Available at: http://dspace.pnpu.edu.ua/handle/123456789/11634 (in Ukrainian)

[12] Krysko V.G. Social Psychology: Dictionary-Reference Book. AST, Moscow, 2001. (in Russian)

[13] Melnyk Ya.G., Krivoruchko N.V. Prolegomenes to Ukrainian Discourse: ethno-cultural, political and lingosemiotic aspects. Publishing house of Vasyl Stefanyk Precarpathian National University, IvanoFrankivsk, 2012. (in Ukrainian)

[14] Michnik A. In Search of Freedom: Essays in History and Politics. Duh i litera, Kyiv, 2009. (in Ukrainian)

[15] Moroz O.O. Political Anatomy of Ukraine. Parlamentske Vydavnytstvo, Kyiv, 2004. (in Ukrainian)

[16] Rudnev V.P. Encyclopedic Dictionary of Culture of the XX-th century. Agraf, Moscow, 2003. (in Russian)

[17] Shchedrovitskiy G.P. Selected Works. Shk.Kult.Polit., Moscow, 1995. (in Russian)

[18] Snyder T. The Reconstruction of Nations: Poland, Ukraine, Lithuania, Belarus, 1569-1999. Duh i litera, Kyiv, 2014. (in Ukrainian)

[19] Astakhova V.I., Bakirov V.S. (Eds.) Sociological Encyclopedia. Akademvydav, Kyiv, 2008. (in Ukrainian)

[20] Osipov H.V. (Ed.) Sociological Encyclopedic Dictionary. Publishing group Norma-INFRA M, Moscow, 1998. (in Russian)

[21] Spengler O. The Sunset of Europe. Outlets on the Morphology of World History. Mysl, Moscow, 1993. (in Russian)

[22] Vasianovych H., Budnyk O. Methodological Principles of Formation of Leadership Qualities of a Future Social Worker. Leader. Elite. Society, 1 (2018), 60-69. doi: 10.20998/2616-3241.2018.1.06 (in Ukrainian)

Address: Anna Gribovycz, Oksana Kondur, Yaroslav Melnyk, Vasyl Stefanyk Precarpathian National University, 57, Shevchenko Str., Ivano-Frankivsk, 76018, Ukraine.

E-mail: anna.serce4@gmail.com; oxikon13@gmail.com; ya_melnyk@gmail.com

Received: 10.01.2019; revised: 29.03.2019. 
Грібович Анна, Кондур Оксана, Мельник Ярослав. Актуалізація лідерства як ключова категорія неокономічного суспільства: соціально-культурні та освітні аспекти. Журнал Прикарпатського університету імені Василя Стефаника, 6 (1) (2019), 50-59.

У статті розгдядається проблема дідерства як ключової категорії у формуванні нової генерації соціально-активних і ділових людей. До нашого часу лідерство та ініціативність описується значною мірою у рамках підготовки вузівської категорії фахівців. Пропонується вивести ії на широкий освітньо-професійний загал і зосередити увагу на вузівській системі. Також запропонована реорганізація системи вищої освіти з урахуванням необхідності актуалізації лідерства як такого. Результати інтерпретуються у рамках гуманітарних, політико-економічних, соціальних та демографічних проблем Європи початку XXI століття.

Кдючові слова: дідерство, освітня система, соціодогія, економічна політика. 